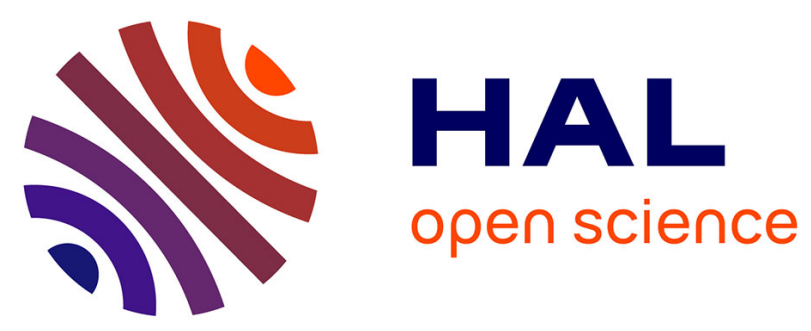

\title{
Rational Optimization of Lewis-Acid Catalysts for the Direct Amination of Alcohols, Part 1 -Activity Descriptors for Metal Triflates and Triflimides
}

Pierre-adrien Payard, Céline Finidori, Laurélia Guichard, Damien Cartigny, Matthieu Corbet, Lhoussain Khrouz, Laurent Bonneviot, Raphael Wischert, Laurence Grimaud, .Marc Pera-titus

\section{To cite this version:}

Pierre-adrien Payard, Céline Finidori, Laurélia Guichard, Damien Cartigny, Matthieu Corbet, et al.. Rational Optimization of Lewis-Acid Catalysts for the Direct Amination of Alcohols, Part 1 -Activity Descriptors for Metal Triflates and Triflimides. European Journal of Organic Chemistry, 2020, 2020 (22), pp.3219-3224. 10.1002/ejoc.202000229 . hal-02997884

\section{HAL Id: hal-02997884 \\ https://hal.sorbonne-universite.fr/hal-02997884}

Submitted on 10 Nov 2020

HAL is a multi-disciplinary open access archive for the deposit and dissemination of scientific research documents, whether they are published or not. The documents may come from teaching and research institutions in France or abroad, or from public or private research centers.
L'archive ouverte pluridisciplinaire HAL, est destinée au dépôt et à la diffusion de documents scientifiques de niveau recherche, publiés ou non, émanant des établissements d'enseignement et de recherche français ou étrangers, des laboratoires publics ou privés. 


\title{
Rational Optimization of Lewis-Acid Catalysts for the Direct Amination of Alcohols, Part 1 - Activity Descriptors for Metal Triflates and Triflimides
}

\author{
Pierre-Adrien Payard,[a,b]* Céline Finidori,[b] Laurélia Guichard,[b] Damien Cartigny, [a] Matthieu \\ Corbet, $[a, c]$ Lhoussain Khrouz,[d] Laurent Bonneviot,[d] Raphael Wischert,[a] Laurence \\ Grimaud[b]* and Marc Pera-Titus[a]*
}

\begin{abstract}
Herein we report a comparison of Lewis acidity indicators (affinity scales, electronegativity, Fukui functions, global electrophilicity index) with a new in silico Beckett-Childs descriptor based on the build-up of partial charge, computed by DFT, on phosphine oxide coordinated to a Lewis acid. When applied to a broad series of triflate and triflimide salts, the last descriptor allowed a qualitative description of catalytic activity trends for the model amination reaction of benzyl alcohol with aniline. A high activity for titanium triflimide was predicted and experimentally confirmed.
\end{abstract}

\section{Introduction}

The direct amination of alcohols is an atom economic strategy to access amines starting from readily available and easy-tohandle alcohols.[1] A variety of non-noble metal, inexpensive, and low-toxic Lewis acids (LAs) have been developed for this reaction in place of complexes based on $\mathrm{Ru}$ or Ir (borrowing $\mathrm{H}_{2}$ reactions), ${ }^{[2]} \mathrm{Pd}$ (Tsuji-type reactions), ${ }^{[3]}$ and Au. ${ }^{[4]}$ Among the best catalysts, metal triflate $\left[\mathrm{M}(\mathrm{OTf})_{\mathrm{n}}\right]$ and triflimide $\left[\mathrm{M}\left(\mathrm{NTf}_{2}\right)_{\mathrm{n}}\right]$ salts, based on $\mathrm{Ca},{ }^{[5]} \mathrm{Al},{ }^{[6]} \mathrm{In},{ }^{[7]} \mathrm{Yb},{ }^{[8]} \mathrm{Bi},{ }^{[9]} \mathrm{Ag},{ }^{[10]} \mathrm{Hg},{ }^{[11]}$ and HOTf as Brønsted acid, ${ }^{[12]}$ stand out. In a previous study on $\mathrm{Al}(\mathrm{OTf})_{3}$, we showed the possibility of extending the amination reaction to electron-rich $\mathrm{N}$-derivatives in nonpolar solvents.[13] However, for this reaction, as for other LA-catalyzed reactions, the choice of the catalyst encompasses a narrow selection of metal salts with scarce attempts for a rationale. Another caveat is that $\mathrm{M}(\mathrm{OTf})_{\mathrm{n}}$ and $\mathrm{M}\left(\mathrm{NTf}_{2}\right)_{n}$ salts are usually poorly characterized (only few XRD structures are available[29,30]) and often contain an important amount of water. For these reasons, robust descriptors are required for predicting the catalytic properties of $\mathrm{M}(\mathrm{OTf})_{\mathrm{n}}$ and $\mathrm{M}\left(\mathrm{NTf}_{2}\right)_{\mathrm{n}}$ salts.

[a] Dr P-A. Payard, C. Finidori, Dr D. Cartigny, Dr. M. Corbet, Dr. R. Wischert, Dr. M. Pera-Titus

Eco-Efficient Products and Processes Laboratory (E2P2L), UMI 3464 CNRS - Solvay, 3966 Jin Du Road, 201108 Shanghai (China)

E-mail: marc.pera-titus-ext@solvay.com

[b] Dr P-A. Payard, L. Guichard, Dr. L. Grimaud

Laboratoire des Biomolécules, LBM, Département de Chimie, École Normale Supérieure, PSL University, Sorbonne Université, CNRS, 75005 Paris, France

E-mail: pierre-adrien.payard@ens.fr, laurence.grimaud@ens.fr

[c] Dr M. Corbet

Solvay - Advanced Organic Chemistry \& Molecule Design Laboratory, 85, rue des Frères Perret, 69192 Saint-Fons, France

[d] L. Khrouz, Prof. L. Bonneviot

Univ. Lyon, ENS de Lyon, CNRS UMR 5182, Université Claude Bernard Lyon 1, Laboratoire de Chimie, F69342, Lyon (France).

Supporting information for this article is given via a link at the end of the document.
LAs play a central role in synthetic chemistry for activating carbon-heteroatom bonds. ${ }^{[14]}$ However, as of today, no general, straightforward, handy scale of Lewis acidity is available for ranking catalysts, and, in particular targeting direct amination reactions. The intrinsic problem emerges from the definition of Lewis acidity: a LA is an electron pair acceptor entity.[15] The main drawback of this definition is that the interaction between an electron vacancy and a doublet (Lewis base, LB) depends on a multiplicity of parameters such as electrostatic interactions, covalent bonding and dispersion forces, which can show a nontrivial contribution to the stability or reactivity of the Lewis-adduct depending on the LB. ${ }^{[16]}$ This drawback is even more apparent in the case of strong LAs such as $\mathrm{M}(\mathrm{OTf})_{\mathrm{n}}$ and $\mathrm{M}\left(\mathrm{NTf} \mathrm{f}_{2}\right)_{\mathrm{n}}$ salts.[17]

Different methods have been proposed to assess the Lewis acidity. The first method relies on experimental or calculated affinities (e.g., Fluoride Ion Affinity,[18] Hydride Ion Affinity,[18b,19] oxophilicity scale[20]), namely the enthalpy or Gibbs free energy of formation of the acid-base adduct. Although the result is doubtless a measure of the Lewis acidity, the relationship between the reactivity and the stability of the Lewis acid-base adduct is a priori not straightforward. However, these methods have proved useful in several cases.[21] The second method is based on the modification of a physical property (e.g., IR wave number, ${ }^{31} \mathrm{P}$ or ${ }^{1} \mathrm{H}$ NMR chemical shift) due to a change of electronic density of a LB probe (Gutmann-Beckett method: phosphine, [22] Childs method: carbonyl,[23] amine,[24] RCN[25]) by transfer to the LA. Overall, we will refer all these related methodologies as "Beckett-Childs method". The measured property should thus be correlated to the electronegativity $(\mathrm{X})$ of a molecule (and not of atoms) as defined by Parr, ${ }^{[26]}$ or the "global electrophilicity ${ }^{\dagger}$ index" (GIE, $\left.\omega\right) .[27]$ Finally, the third method consists of measuring rate constants for LA-catalyzed model reactions.[22d,28] However, the rate constants are not directly correlated to the Lewis acidity, but rather to the electrophilicity. ${ }^{[15]}$ In practice, all the above three methods are hardly used by organic chemists: the scales are difficult to handle, it is arduous to add a new LA to an already established series, and the sets of reported data are usually incomplete and rely on the experimental conditions. In this view, it is of prior necessity to develop a quantitative and easy-to-handle scale of Lewis acidity to assist the organic chemist in the choice of LAs.

Here we evaluated a comprehensive library of $M(\mathrm{OTf})_{n}$ and $\mathrm{M}\left(\mathrm{NTf}_{2}\right)_{\mathrm{n}}$ salts on the model amination reaction of benzyl alcohol with aniline. The reactivity was contrasted to a large set of experimental and theoretical descriptors belonging to the three methods listed above. In particular, a new theoretical descriptor based on the partial charge build-up of a LB coordinated to a LA (method 2) exhibited an excellent correlation with the catalytic activity for the model amination reaction between benzyl alcohol $(\mathrm{BnOH})$ and aniline. This descriptor led us to synthetize a new $\mathrm{Ti}$ 
triflimide salt, which indeed showed a remarkable catalytic activity, thus validating our approach.

\section{Results and Discussion}

\section{Experimental trends for $\mathrm{BnOH}$ amination with aniline}

In a first stage of our study, a series of non-noble $\mathrm{M}(\mathrm{OTf})_{\mathrm{n}}$ and $\mathrm{M}\left(\mathrm{NTf}_{2}\right)_{n}$ salts were screened on the model amination reaction between $\mathrm{BnOH}(\mathbf{1} \mathbf{a})$ and aniline (2a) in toluene, ${ }^{[13]}$ targeting the formation of $\mathrm{N}$-benzylaniline (3aa) (Figure 1 ; see Table 1 for $\mathrm{M}\left(\mathrm{NTf}_{2}\right)_{\mathrm{n}}$ salts, Table $\mathrm{S} 1$ for $\mathrm{M}(\mathrm{OTf})_{\mathrm{n}}$ salts). These salts are very hygroscopic and accordingly were kept under static vacuum on phosphorous pentoxide before use. Despite this precaution, amination reactions were not performed under inert atmosphere, since water is formed during the reaction. Several general trends emerged from these results. As a rule, triflimides gave better results than triflates, matching earlier studies.[17b] Both alkaline and alkaline-earth metals displayed very low activity. Likewise, late transition metals were not efficient. In contrast, high yields were obtained using early transition metals, pblock metals and lanthanides. Noteworthy, this behavior differs from that reported by Kobayashi and co-workers for Mukaiyama reaction in wet THF catalyzed by various $\mathrm{MX}_{\mathrm{n}}$ salts $\left(\mathrm{X}=\mathrm{Cl}\right.$, OTf, $\left.\mathrm{ClO}_{4}\right)$.[28b]

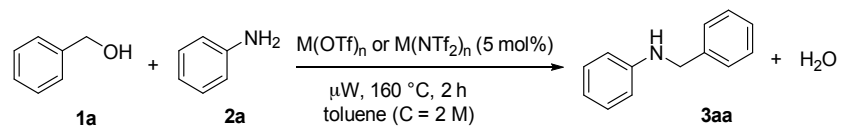

Figure 1. Direct amination of $\mathrm{BnOH} \mathbf{1 a}$ by aniline $\mathbf{2 a}$ in the presence of $\mathrm{M}(\mathrm{OTf})_{\mathrm{n}}$ or $\mathrm{M}\left(\mathrm{NTf}_{2}\right)_{\mathrm{n}}$ catalysts (reaction 1$)$.

Table 1. Screening of $\mathrm{M}\left(\mathrm{NTf}_{2}\right)_{\mathrm{n}}$ salts on the model amination reaction $(1 \mathrm{a}+2 \mathrm{a}$ = 3aa). Additional results on M(OTf) $)_{n}$ salts can be found in the SI (Table S1)

\begin{tabular}{|c|c|c|c|}
\hline Catalyst & Yield (\%)a & Catalyst & Yield $(\%)^{a}$ \\
\hline- & $<1$ & $\mathrm{Fe}\left(\mathrm{NTf}_{2}\right)_{3}$ & 32 \\
\hline $\mathrm{HNTf}_{2}$ & $<1$ & $\mathrm{Y}\left(\mathrm{NTf}_{2}\right)_{3}$ & 37 \\
\hline $\mathrm{Ba}\left(\mathrm{NTf}_{2}\right)_{2}$ & 0 & $\ln \left(\mathrm{NTf}_{2}\right)_{3}$ & 37 \\
\hline $\mathrm{Cd}\left(\mathrm{NTf}_{2}\right)_{2}$ & 0 & $\mathrm{La}\left(\mathrm{NTf}_{2}\right)_{3}$ & 46 \\
\hline $\mathrm{Sr}\left(\mathrm{NTf}_{2}\right)_{2}$ & 0 & $\mathrm{Ga}\left(\mathrm{NTf}_{2}\right)_{3}$ & 48 \\
\hline $\mathrm{Ni}\left(\mathrm{NTf}_{2}\right)_{2}$ & 0 & $\mathrm{Cr}\left(\mathrm{NTf}_{2}\right)_{3}$ & 49 \\
\hline $\mathrm{K}\left(\mathrm{NTf}_{2}\right)$ & $<1$ & $\mathrm{Sc}\left(\mathrm{NTf}_{2}\right)_{3}$ & 51 \\
\hline $\mathrm{Cu}\left(\mathrm{NTf}_{2}\right)_{2}$ & $<1$ & $\mathrm{Bi}\left(\mathrm{NTf}_{2}\right)_{3}$ & 51 \\
\hline $\mathrm{Ca}\left(\mathrm{NTf}_{2}\right)_{2}$ & $<1$ & $\mathrm{Al}\left(\mathrm{NTf}_{2}\right)_{3}$ & 52 \\
\hline $\mathrm{Li}\left(\mathrm{NTf}_{2}\right)$ & $<1$ & $\mathrm{Ho}\left(\mathrm{NTf}_{2}\right)_{3}$ & 58 \\
\hline $\mathrm{Cs}\left(\mathrm{NTf}_{2}\right)$ & $<1$ & $\mathrm{Sm}\left(\mathrm{NTf}_{2}\right)_{3}$ & 59 \\
\hline $\mathrm{Mg}\left(\mathrm{NTf}_{2}\right)_{2}$ & 5 & $\mathrm{Gd}\left(\mathrm{NTf}_{2}\right)_{3}$ & 67 \\
\hline $\mathrm{Zn}\left(\mathrm{NTf}_{2}\right)_{2}$ & 9 & $\mathrm{Sb}\left(\mathrm{NTf}_{2}\right)_{3}$ & 72 \\
\hline $\mathrm{Co}\left(\mathrm{NTf}_{2}\right)_{2}$ & 11 & $\mathrm{Nd}\left(\mathrm{NTf}_{2}\right)_{3}$ & 73 \\
\hline $\mathrm{Mn}\left(\mathrm{NTf}_{2}\right)_{2}$ & 25 & $\operatorname{Pr}\left(\mathrm{NTf}_{2}\right)_{3}$ & 80 \\
\hline $\mathrm{Ce}\left(\mathrm{NTf}_{2}\right)_{3}$ & 29 & $\mathrm{Eu}\left(\mathrm{NTf}_{2}\right)_{3}$ & 87 \\
\hline $\begin{array}{l}\text { a Measured } \\
\text { by }{ }^{1} \mathrm{H} \text { NMR. }\end{array}$ & & $\mathrm{Yb}\left(\mathrm{NTf}_{2}\right)_{3}$ & 88 \\
\hline
\end{tabular}

\section{Experimental descriptors of Lewis acids}

We were curious to figure out if the above trends would hold for other LA-catalyzed amination reactions. To this aim, we chose a second amination reaction using electron-poor $\mathrm{N}$-derivatives in a polar and non-coordinating solvents (Figure 2 upper part).[8a,13] The kinetics of formation of the amination product $\mathbf{3 b b}$ was monitored by ${ }^{19} \mathrm{~F}$ NMR. The first order rate constant was measured using several $\mathrm{M}(\mathrm{OTf})_{\mathrm{n}}$ salts $\left(\mathrm{M}=\mathrm{La}^{3+}, \mathrm{Al}^{3+}, \mathrm{Fe}^{3+}\right.$, $\left.\mathrm{Bi}^{3+}\right)$. The reactivity order for both amination reactions (1 and 2) was qualitatively similar and decreased in the sense $\mathrm{Bi}^{3+}>\mathrm{Fe}^{3+}$ $>\mathrm{Al}^{3+}>\mathrm{La}^{3+}$ for M(OTf)n salts (Table S1, Figure S1). Note that the rate constants suffer from unknown hydration, which can be variable for the different salts. In all cases, the ether resulting from self-condensation (1 $\mathbf{b}$ ') was observed as by-product.[13]

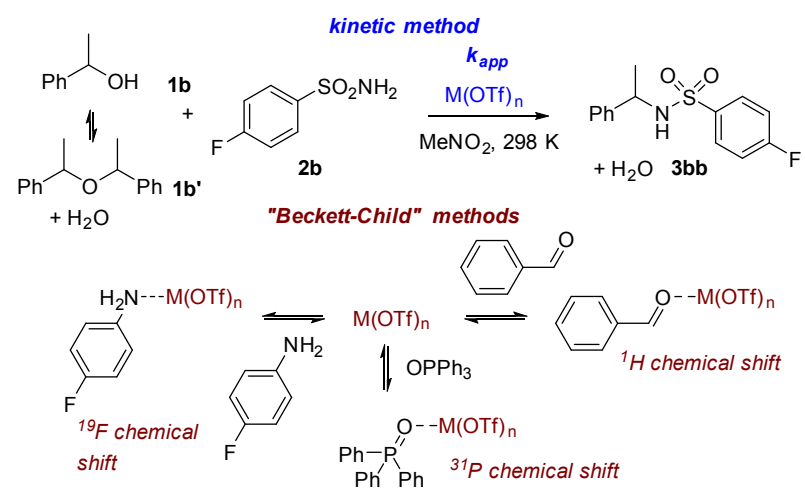

Figure 2. Amination of phenylethanol $\mathbf{1 b}$ and $p$-fluorophenyl sulfonamide $\mathbf{2 b}$ (reaction 2).

We then investigated the convenience of the "Beckett-Childs methods" to estimate the Lewis acidity and achieve proper correlation with the catalytic results for reaction 1.[23] These methods depend on the variation of NMR chemical shift associated with the formation of a Lewis adduct to assess the electron withdrawing power of a LA (Figure 2, bottom part). First, heteronuclear ${ }^{19} \mathrm{~F}$ and ${ }^{31} \mathrm{P}$ NMR were used as LB probes, as the chemical shifts are larger than those typically measured on ${ }^{1} \mathrm{H}$ NMR and do not require deuterated solvents. Under LA excess, to form mainly a 1:1 Lewis adduct, both $p$-fluoroaniline and triphenylphosphine oxide resonances are strongly deshielded (Figures S2-S3).[24] However, the chemical shift variation induced by the different $\mathrm{M}(\mathrm{OTf})_{\mathrm{n}}$ salts did not match the reactivity order. $\neq$ Benzaldehyde was then tested as ${ }^{1} \mathrm{H}$ and ${ }^{13} \mathrm{C}$ NMR probes. Under LA excess,,[17b] a down-field shift of all resonances was observed (Figure S4), which can be attributed to electron-withdrawing effects.[23b] In this case, it was indeed possible to correlate the variation of the chemical shift with the reactivity.

Overall, "Beckett and Childs methods" are not convenient for $\mathrm{M}(\mathrm{OTf})_{\mathrm{n}}$ and $\mathrm{M}\left(\mathrm{NTf}_{2}\right)_{\mathrm{n}}$ salts, as they require expensive deuterated nitromethane and even in this solvent, the solubility of these salts is very low. Moreover, as stated above the hydration level of both salts and the solvent is difficult to assess. To circumvent these limitations, we turned our attention into theoretical descriptors. 

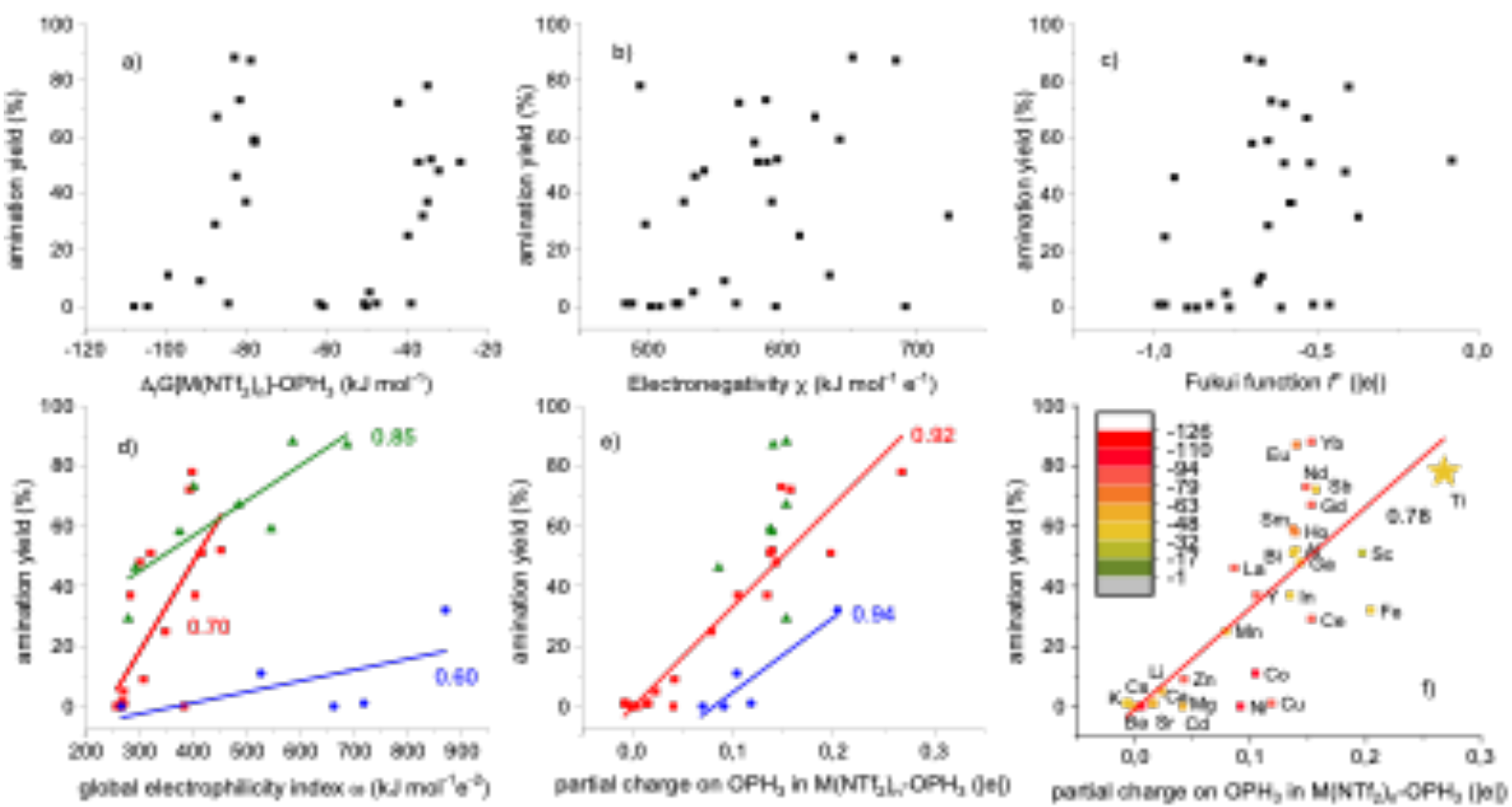

partal chorge on $\mathrm{CPH}_{3}$ in $\mathrm{NWTH}_{2} \mathrm{OPH}_{3} 0 \mathrm{eO}$

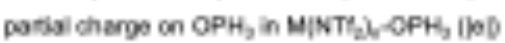

Figure 3. Tentative correlations between the yield of the amination reaction 1 catalyzed by $M\left(N T f_{2}\right)_{n}(\mathbf{1 a}+\mathbf{2 a}=\mathbf{3 a a})$ and: a) binding free energy of OPH $\mathrm{H}_{3}$ to

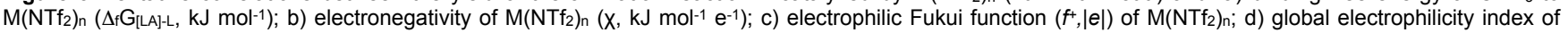
$\mathrm{M}\left(\mathrm{NTf}_{2}\right)_{3}\left(\omega, \mathrm{kJ} \mathrm{mol}^{1} \mathrm{e}^{-2}\right)$; e) and f) partial charge on $\mathrm{OPH}_{3}$ in the complex $\mathrm{M}\left(\mathrm{NTf}_{2}\right)_{\mathrm{n}}-\mathrm{OPH}_{3}(|\mathrm{e}|)$. In d) and e), lanthanide salts are displayed in green, late-transitionmetal salts in blue, others in red. In f) the color indicates the binding free energy of the salt to $\mathrm{OPH}_{3}$, as a quantification of possible poisoning.

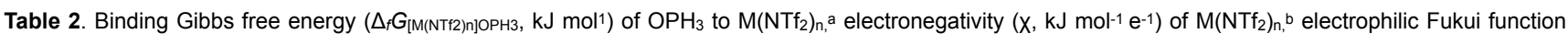

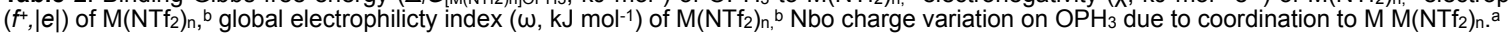

\begin{tabular}{|c|c|c|c|c|c|c|c|c|c|c|c|}
\hline Triflimide salt & $\begin{array}{c}\Delta_{f} G[L A]-L \\
(\mathrm{~kJ} \\
\left.\mathrm{mol}^{-1}\right)\end{array}$ & $\begin{array}{c}\mathrm{X} \\
\left(\mathrm{kJ} \mathrm{mol}^{-1}\right. \\
\left.\mathrm{e}^{-1}\right)\end{array}$ & $\begin{array}{c}\omega \\
(\mathrm{kJ} \mathrm{mol}-1 \\
\left.\mathrm{e}^{-2}\right)\end{array}$ & $f^{+}(|e|)$ & $\begin{array}{c}\text { Charge } \\
\text { on } \mathrm{OPH}_{3} \\
(\mathrm{e})\end{array}$ & Triflimide salt & $\begin{array}{c}\Delta_{f} G_{[L A]-L} \\
(\mathrm{~kJ} \\
\left.\mathrm{mol}^{-1}\right)\end{array}$ & $\begin{array}{c}\mathrm{X} \\
(\mathrm{kJ} \\
\left.\mathrm{mol}^{-1}\right)\end{array}$ & $\begin{array}{c}\omega \\
\left(\mathrm{kJ} \mathrm{mol}^{-1}\right. \\
\left.\mathrm{e}^{-2}\right)\end{array}$ & $f^{+}(|\mathrm{e}|)$ & $\begin{array}{c}\text { Charge } \\
\text { on } \mathrm{OPH}_{3} \\
\text { (e) }\end{array}$ \\
\hline $\mathrm{Ag}\left(\mathrm{NTf}_{2}\right)_{3}$ & -76.67 & 520.29 & 265.92 & $-0,92$ & 0.070 & $\mathrm{Lu}\left(\mathrm{NTf}_{2}\right)_{3}$ & -72.57 & 521.14 & 270.72 & $-0,71$ & 0.125 \\
\hline $\mathrm{Al}\left(\mathrm{NTf}_{2}\right)_{3}$ & -34.10 & 596.15 & 451.27 & $-0,08$ & 0.139 & $\mathrm{Mg}\left(\mathrm{NTf}_{2}\right)_{2}$ & -49.37 & 533.67 & 269.62 & $-0,78$ & 0.023 \\
\hline $\mathrm{Au}\left(\mathrm{NTf}_{2}\right)$ & -119.83 & 633.94 & 537.60 & $-0,8$ & 0.137 & $\begin{array}{l}\operatorname{Mn}\left(\mathrm{NTf}_{2}\right)_{2}(\mathrm{~S}= \\
5 / 2)\end{array}$ & -39.84 & 612.73 & 346.74 & $-0,97$ & 0.079 \\
\hline $\mathrm{Ba}\left(\mathrm{NTf}_{2}\right)_{2}$ & -60.84 & 508.45 & 266.41 & $-0,9$ & -0.001 & $\mathrm{Na}\left(\mathrm{NTf}_{2}\right)$ & -48.74 & 515.25 & 291.29 & $-0,61$ & 0.000 \\
\hline $\mathrm{Bi}\left(\mathrm{NTf}_{2}\right)_{3}$ & -37.18 & 581.57 & 415.35 & $-0,6$ & 0.137 & $\begin{array}{l}\mathrm{Nd}\left(\mathrm{NTf}_{2}\right)_{3}(\mathrm{~S}= \\
3 / 2)\end{array}$ & -81.60 & 587.56 & 400.92 & $-0,64$ & 0.148 \\
\hline $\mathrm{Ca}\left(\mathrm{NTf}_{2}\right)_{2}$ & -50.69 & 522.96 & 268.54 & $-0,83$ & 0.015 & $\mathrm{Ni}\left(\mathrm{NTf}_{2}\right)_{2}(\mathrm{~S}=1)$ & -104.45 & 691.54 & 660.93 & $-0,61$ & 0.091 \\
\hline $\mathrm{Cd}\left(\mathrm{NTf}_{2}\right)_{2}$ & -50.19 & 594.99 & 382.41 & $-0,77$ & 0.041 & $\mathrm{~Pb}\left(\mathrm{NTf}_{2}\right)_{2}$ & -75.88 & 578.92 & 396.92 & $-0,8$ & 0.071 \\
\hline $\begin{array}{l}\mathrm{Co}\left(\mathrm{NTf}_{2}\right)_{2}(\mathrm{~S}= \\
3 / 2)\end{array}$ & -99.37 & 634.99 & 525.15 & $-0,67$ & 0.104 & $\begin{array}{l}\operatorname{Pm}\left(\mathrm{NTf}_{2}\right)_{3}(\mathrm{~S}= \\
\text { 2) }\end{array}$ & -82.20 & 593.07 & 412.47 & $-0,65$ & 0.147 \\
\hline $\mathrm{Cs}\left(\mathrm{NTf}_{2}\right)$ & -39.06 & 565.51 & 265.34 & $-0,99$ & -0.008 & $\operatorname{Pt}\left(\mathrm{NTf}_{2}\right)_{2}$ & -1.11 & 564.06 & 445.89 & $-0,38$ & 0.247 \\
\hline $\mathrm{Cu}\left(\mathrm{NTf}_{2}\right)$ & -125.43 & 707.12 & 395.39 & $-0,89$ & 0.073 & $\mathrm{Rb}\left(\mathrm{NTf}_{2}\right)$ & -45.84 & 489.22 & 272.33 & $-0,99$ & -0.008 \\
\hline $\begin{array}{l}\mathrm{Cu}\left(\mathrm{NTf}_{2}\right)_{2}(\mathrm{~S}= \\
1 / 2)\end{array}$ & -84.41 & 483.05 & 716.76 & $-0,51$ & 0.118 & $\mathrm{Sb}\left(\mathrm{NTf}_{2}\right)_{3}$ & -42.23 & 567.62 & 392.75 & $-0,6$ & 0.157 \\
\hline $\operatorname{Er}\left(\mathrm{NTf}_{2}\right)_{3}(\mathrm{~S}=3 / 2)$ & $-75,72$ & 565.33 & 353.65 & $-0,7$ & 0.135 & $\mathrm{Sc}\left(\mathrm{NTf}_{2}\right)_{3}$ & -26.89 & 588.28 & 320.04 & $-0,52$ & 0.197 \\
\hline $\mathrm{Eu}\left(\mathrm{NTf}_{2}\right)_{3}(\mathrm{~S}=3)$ & -78.85 & 684.37 & 685.83 & $-0,67$ & 0.140 & $\begin{array}{l}\operatorname{Sm}\left(\mathrm{NTf}_{2}\right)_{3}(\mathrm{~S}= \\
5 / 2)\end{array}$ & -77.98 & 642.57 & 544.53 & $-0,65$ & 0.137 \\
\hline $\begin{array}{l}\mathrm{Fe}\left(\mathrm{NTf}_{2}\right)_{3}(\mathrm{~S}= \\
5 / 2)\end{array}$ & -36.16 & 723.51 & 868.69 & $-0,37$ & 0.204 & $\mathrm{Sn}\left(\mathrm{NTf}_{2}\right)_{2}$ & -76.40 & 559.54 & 368.76 & $-0,77$ & 0.082 \\
\hline $\mathrm{Ga}\left(\mathrm{NTf}_{2}\right)_{3}$ & -32.21 & 541.61 & 300.70 & $-0,41$ & 0.143 & $\operatorname{Sr}\left(\mathrm{NTf}_{2}\right)_{2}$ & -107.80 & 501.73 & 256.57 & $-0,87$ & 0.005 \\
\hline
\end{tabular}




\begin{tabular}{|c|c|c|c|c|c|c|c|c|c|c|c|}
\hline $\mathrm{Ho}\left(\mathrm{NTf}_{2}\right)_{3}(\mathrm{~S}=2)$ & -77.87 & 579.15 & 374.27 & $-0,7$ & 0.139 & $\operatorname{Tm}\left(\mathrm{NTf}_{2}\right)_{3}(\mathrm{~S}=1)$ & -67.28 & 608.13 & 451.24 & $-0,71$ & 0.136 \\
\hline $\ln \left(\mathrm{NTf}_{2}\right)_{3}$ & $-34,99$ & 592.12 & 403.09 & $-0,58$ & 0.134 & $\mathrm{~V}\left(\mathrm{NTf}_{2}\right)_{3}(\mathrm{~S}=1)$ & -42.21 & 610.76 & 457.21 & $-0,37$ & 0.285 \\
\hline $\operatorname{Ir}\left(\mathbf{N T f}_{2}\right)_{3}$ & -51.10 & 534.66 & 385.34 & $-0,27$ & 0.316 & $\begin{array}{l}\mathrm{Yb}\left(\mathrm{NTf}_{2}\right)_{3}(\mathrm{~S}= \\
1 / 2)\end{array}$ & -82.89 & 652.24 & 584.28 & $-0,71$ & 0.153 \\
\hline $\mathrm{K}\left(\mathrm{NTf}_{2}\right)$ & -47.69 & 487.98 & 267.78 & $-0,97$ & -0.006 & $\mathrm{Y}\left(\mathrm{NTf}_{2}\right)_{3}$ & -80.06 & 526.60 & 282.13 & $-0,58$ & 0.105 \\
\hline $\mathrm{La}\left(\mathrm{NTf}_{2}\right)_{3}$ & -82.53 & 534.76 & 292.16 & $-0,94$ & 0.086 & $\mathrm{Zn}\left(\mathrm{NTf}_{2}\right)_{3}$ & -91.40 & 556.79 & 307.16 & $-0,68$ & 0.042 \\
\hline $\mathrm{Li}\left(\mathrm{NTf}_{2}\right)$ & -61.78 & 520.24 & 268.63 & $-0,46$ & 0.015 & $\begin{array}{l}\mathrm{Zr}\left(\mathrm{NTf}_{2}\right)_{3}(\mathrm{~S}= \\
1 / 2)\end{array}$ & -4.97 & 338.35 & 206.36 & $-0,44$ & 0.215 \\
\hline
\end{tabular}

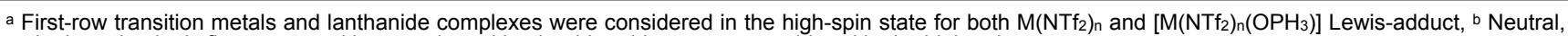
cationic and anionic first-row transition metals and lanthanide adducts were considered in the high-spin state.

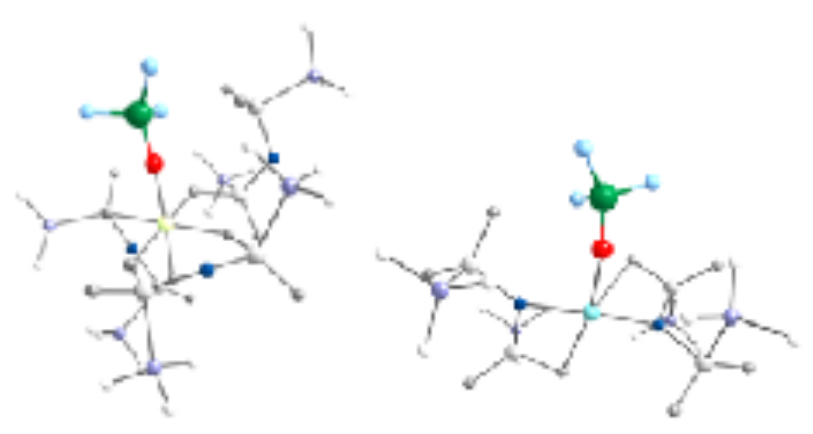

Figure 4. Optimized $3 \mathrm{D}$ structures of $\left[\mathrm{Al}\left(\mathrm{NTf}_{2}\right)_{3}-\mathrm{OPH}_{3}\right]$ and $\left[\mathrm{Cu}\left(\mathrm{NTf}_{2}\right)_{2}-\mathrm{OPH}_{3}\right]$ adducts.

\section{Theoretical descriptors of Lewis acids}

The 3D structure of a large series of $M(O T f)_{n}$ and $M\left(N_{T} f_{2}\right)_{n}$ salts was optimized at the BP86-D3(BJ)/def2-SVP level, while the electronic energy was estimated at the B3LYP-D3(BJ)/def2TZVP level using the method previously reported for $\mathrm{Al}(\mathrm{OTf})_{3}$ (see Computational Details in SI).[13] At this level of theory, triflates behaved as bidentate ligands in all structures with two $O$ atoms coordinated to the metal cation (Figure 4, Figures S5-S9), matching earlier studies.[29] The case of triflimides was more challenging, since this anion could coordinate to a metal cation either via $\mathrm{N}$ or $\mathrm{O}$ atoms (see $\mathrm{SI}$ for a complete discussion on this point, Figures S10-S15, Tables S2-S3).[30]

With these structures in hand, several descriptors, either intrinsic or related to a given LA-LB adduct, were calculated for $\mathrm{M}(\mathrm{OTf})_{n}$ and $\mathrm{M}\left(\mathrm{NTf}_{2}\right)_{\mathrm{n}}$. Note that the bare $\mathrm{M}^{\mathrm{n}+}$ cannot be used as a model for the salts due to the large cation-dependent errors associated to the energy of naked cations (in gas phase). The descriptors include (see definitions in SI): (1) an affinity scale based on the binding free energy of $\mathrm{OPH}_{3}$ to the LA metal salt ( $\Delta G_{[L A-O P H 3]}$, Tables 2 and S4-S5), (2) the Parr electronegativity ( $X$, Tables S6-S7), (3) the hardness ( $\eta$ ) and global electrophilicity index ( $\omega$, Tables 2 and S8-S9), and (4) the Fukui function $\left(f^{+}\right.$, Tables 2 and S10-S11) for addition of an electron to the metal center. The affinity scale based on the $\left[\mathrm{LA}-\mathrm{OPH}_{3}\right]$ binding energy was first investigated. $\mathrm{OPH}_{3}$ was chosen as a molecular probe due to its small size and formation of stable Lewis adducts. Comparable trends were obtained using the enthalpy and free energy as descriptors, since entropic effects were of the same order of magnitude (Figure S16). When comparing the binding energy of $\mathrm{OPH}_{3}$ to $\mathrm{M}(\mathrm{OTf})_{n}$ and $\mathrm{M}\left(\mathrm{NTf}_{2}\right)_{n}$, a rough trend was found, with $\mathrm{M}(\mathrm{OTf})_{\mathrm{n}}$ salts generally featuring higher binding energy (Figure S17). Overall, this descriptor proved meaningless with respect to the catalytic properties of the different salts. This was clearly evidenced by plotting the yield of 3aa against the affinity, showing no correlation (Figure 3a). Alternatively, the Parr electronegativity, the global electrophilicity index and the electrophilic Fukui function are potential descriptors of reactivity, as they should describe the ability of a LA to withdraw electronic density from a LB. Nonetheless, any attempt to correlate all these descriptors with the yield of 3aa was not fruitful, even if the global electrophilicity index reproduced acceptably the experimental trend (Figure 3b-3d).

The poor predictive level of the descriptors above contrast with the promising correlations attained using the experimental Beckett-Childs method (vide supra). Inspired by this observation, we developed an in silico analogous method using $\mathrm{OPH}_{3}$ as molecular probe (Tables 2 and S12-S13, Figure 3e). The charge variation on $\mathrm{OPH}_{3}$ upon formation of a 1:1 Lewis adduct with $\mathrm{M}(\mathrm{OTf})_{\mathrm{n}}$ and $\mathrm{M}\left(\mathrm{NTf}_{2}\right)_{\mathrm{n}}$ was calculated on the whole $\mathrm{OPH}_{3}$ molecule using NBO analysis (the charge on O-atoms may increase or decrease upon coordination due to variable polarization of the P-O bond) (Tables 2, S12-S13)[31] To our delight, good prediction level was achieved between the yield of 3aa and the charge variation for $\mathrm{M}\left(\mathrm{NTf}_{2}\right)_{\mathrm{n}}$ salts (Figure $3 \mathrm{e}$ ). The electron withdrawal from $\mathrm{OPH}_{3}$ was higher for $\mathrm{M}\left(\mathrm{NTf}_{2}\right)_{\mathrm{n}}$ salts, which correlates with their higher catalytic activity (Figure S19). Among $\mathrm{M}\left(\mathrm{NTf}_{2}\right)_{n}$ salts, those based on late transition metals followed a consistent trend, but displayed lower activity (Figure $3 e-f)$. This observation might be ascribed to a higher poisoning of these salts, as they also exhibit higher affinity for $\mathrm{OPH}_{3}$ (Figure $3 a$ and $3 f$ ). Besides, the behavior of lanthanide salts was not well reproduced (Figure $3 e$ ), most likely due to the intrinsic difficulty to model lanthanide metals by DFT.

The potential links between the different indicators would be of interest. In particular, it is remarkable that the charge exchange from the LB to $M(O T f)_{n}$ and $M\left(N T f_{2}\right)_{n}$ is completely independent of the stability of the Lewis adduct formed. Accordingly, affinity scales can be misleading to predict catalytic activity. On the contrary, the global electrophilicity index provides a rough correlation with the experimental results (Figure $3 \mathrm{~d}$ ). This is reasonable as both our new indicator - based on the partial charge withdrawal from a real LB upon coordination - and global electrophilicity are designed to quantify the ability of a system to accept electronic density (see the SI for a definition of global electrophilicity). The poor ability of global electrophilicity, compared to partial charge, to describe the behavior of triflimides is probably due to the strong assumptions considered in its calculation that consist of no geometric relaxation (fixed potential) and transfer of one electron instead of partial density transfer.

The good correlation between the new in silico BeckettChilds descriptor of Lewis acidity and the experimental reactivity trends prompted us to investigate the potential reactivity of $\mathrm{M}\left(\mathrm{NTf}_{2}\right)_{\mathrm{n}}$ salts that have not been previously tested. For this purpose, structure optimization and charge calculation were determined for various triflimide salts with a very low calculation cost (Table 2). Among the different salts assessed by this 
method, a promising catalytic activity was predicted for $\mathrm{Ti}(\mathrm{III})$ triflimide (Figure 3f). This computed design prompted us to try out the synthesis of this salt, which to the best of our knowledge has never been described.

\section{Titanium Triflimide: a New Catalyst for Alcohol Amination}

To our knowledge, only one report is available describing the tentative synthesis of $\mathrm{Ti}(\mathrm{OTf})_{4}{ }^{[31]}$ The main shortcoming of $\mathrm{Ti}$ salts relies on their propensity to form $\mathrm{TiO}_{2}$ in the presence of water. Encouraged by the anticipated high catalytic activity of $\mathrm{Ti}$, we attempted the synthesis of $\mathrm{Ti}\left(\mathrm{NTf}_{2}\right)_{\mathrm{n}}$ by addition of excess trifluoromethanesulfonimide $\left(\mathrm{HNTf}_{2}\right)$ on metal $\mathrm{Ti}$ in water. A pale pink solution was obtained after two days under reflux. Water and excess $\mathrm{HNTf}_{2}$ were removed under vacuum to give a pink solid 4. $\$$ This color was rather unexpected for a Ti(IV) salt and to understand its origin, a set of analyses of $\mathbf{4}$ was performed (see Section 4 in SI for details). The analyses allowed the detection of $20 \% \mathrm{Ti}(\mathrm{III})$ in solid 4 , which was surprising with regards to the experimental conditions used [i.e. water, air, prolonged heating, Figure S20). This was further confirmed by Electron Paramagnetic Resonance (EPR). In THF, the EPR spectrum of 4 featured the symmetric pattern of a Ti-centered single radical without Jahn-Teller effect $\left(g_{\text {iso }}=1.960\right)$ (Figure 5 , see the SI, Figures S21-S22 for EPR spectra of the solid $\mathbf{4}$ and $\mathbf{4}$ in solution in toluene). On the basis of these data, the molecular formula of $\mathrm{Ti}^{\prime \prime \prime}{ }_{0.2} \mathrm{TilV}_{0.8}\left(\mathrm{NTf}_{2}\right)_{2}(\mathrm{O})_{\mathrm{x}}(\mathrm{OH})_{\mathrm{y}}\left(\mathrm{H}_{2} \mathrm{O}\right)_{\mathrm{z}} \cdot 2.5 \mathrm{H}_{2} \mathrm{O}$ was tentatively assigned to compound 4 .

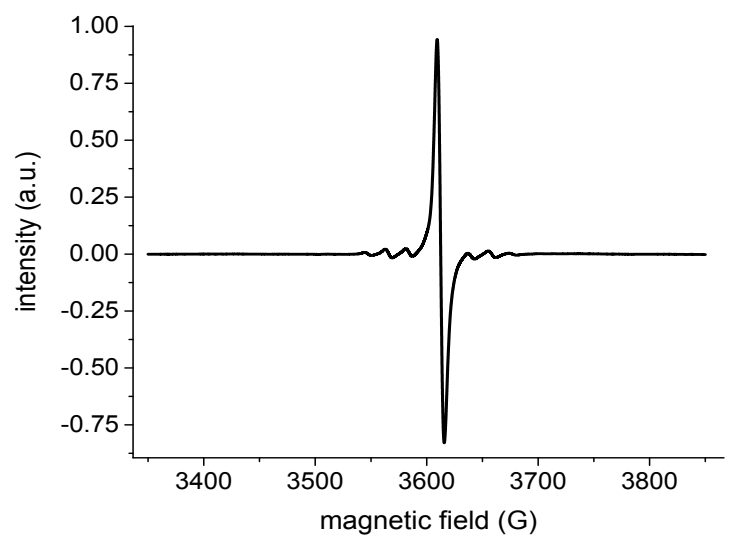

Figure 5. EPR spectrum of 4 in THF at RT $\left(g_{\text {iso }}=1.96, a_{\text {iso }}=18 \mathrm{G}\right)$.

Finally, complex 4 was tested in the direct amination of $\mathrm{BnOH}$ with aniline. To our delight, the desired product 3aa was obtained in $78 \%$ isolated yield with a good selectivity, matching the prediction (Figure $3 \mathrm{f}$, star-shaped point). $f$

\section{Conclusion}

In summary, we developed an "in silico Beckett-Childs" descriptor based on the DFT-predicted partial charge transferred from phosphine oxide $\left(\mathrm{OPH}_{3}\right)$ to a Lewis acid. The use of this descriptor allowed us to predict promising activity for $\mathrm{Ti}\left(\mathrm{NTf}_{2}\right)_{3}$ for the direct amination of benzyl alcohol. This theoretical design led us to the synthesis of a new Ti triflimide complex, which proved to be an active catalyst for the reaction. The catalytic activity of this complex is reported in the second part of this work (Part II). We hope that this handy theoretical descriptor of Lewis acidity, readily obtained from a single structure optimization and charge calculation, and encompassing very low calculation cost, will stand out in the future to rank Lewis acids. The use of this descriptor to the DFT-assisted optimization of other Lewis-acid catalyzed reactions is currently in progress in our team.

\section{Acknowledgements}

This work was funded by CNRS and Solvay. P.-A. Payard is grateful to ENS Paris Saclay for a PhD grant. The authors would like to thank DCM, UMR5250, IR-RPE CNRS FR3443 RENARD network are for the use of EPR facilities. Dr llaria Ciofini from PSL University - ChimieParisTech is kindly acknowledged for precious assistance and fruitful discussion.

Keywords: Becketts-Child - Lewis Acidity - DFT - Titanium Triflimide $\bullet$ Lewis acid descriptors

\section{Notes}

$\dagger \quad$ The term was poorly-chosen, as "electrophilicity" refers to a kinetic rather than thermodynamic property, see ref $18 \mathrm{a}$.

$\ddagger \quad$ These observations are coherent with the results reported in ref $18 \mathrm{~b}$. These are not surprising, as the ${ }^{31} \mathrm{P}$ NMR chemical shift cannot be easily correlated to electronic effects, see also J. Tong, S. Liu, S. Zhang, S. Z. Li, Spectrochim. Acta A: Mol. Biomol. Spec. 2007, 67, 837-846.

$\S \quad \mathrm{HNTf}_{2}$ sublimates under vacuum at about $60{ }^{\circ} \mathrm{C}$, see Sun, J. Triflimide Encyclopedia of Reagents for Organic Synthesis, Wiley- $\mathrm{VCH}$ Weinheim, 2010. Note than one must not heat over $100{ }^{\circ} \mathrm{C}$ to avoid the decomposition of the salt according to the reaction: $\mathrm{Ti}\left(\mathrm{H}_{2} \mathrm{O}\right)\left(\mathrm{NTf}_{2}\right)->$ $\mathrm{Ti}(\mathrm{OH})+\mathrm{HNTf}_{2}$, see TGA section.

[1] a) E. Emer, R. Sinisi, M. G. Capdevila, D. Petruzziello, F. De Vincentiis P. G. Cozzi, Eur. J. Org. Chem. 2011, 2011, 647-666; b) M. Pera-Titus, F. Shi, ChemSusChem. 2014, 7, 720-722; c) S. Bähn, S. Imm, L. Neubert, M. Zhang, H. Neumann, M. Beller, ChemCatChem. 2011, 3, 1853-1864; d) A. Baeza, C. Nájera, Synthesis, 2014, 46, 25-34.

[2] a) T. D. Nixon, M. K. Whittlesey, J. M. J. Williams, Dalton Trans. 2009 753-762; b) G. Guillena, D. J. Ramón, M. Yus, Chem. Rev. 2010, 110 1611-1641; d) J. L. Klinkenberg, J. F. Hartwig, Angew. Chem. Int. Ed. 2011, 50, 86-95; e) C. Gunanathan, D. Milstein, Science 2013, 341, 1229712; f) Q. Yang, Q. Wang, Z. Yu, Chem. Soc. Rev. 2015, 44 2305-2329.

[3] a) H. Bricout, J.-F. Carpentier, A. Mortreux, J. Mol. Catal. A: Chem 1998, 136, 243-251; b) Y. Gumrukcu, B. de Bruin, J. N. H. Reek Catalysts 2015, 5, 349-365; c) S. Sawadjoon, P. J. R. Sjöberg, A. Orthaber, O. Matsson, J. S. M. Samec, Chem. Eur. J. 2014, 20 , 1520-1524; d) J. Muzart, Eur. J. Org. Chem. 2007, 2007, 3077-3089.

[4] a) V. Terrasson, S. Marque, M. Georgy, J.-M. Campagne, D. Prim, Adv. Synth. Catal. 2006, 348, 2063-2067; b) T. Ohshima, Y. Nakahara, J. Ipposhi, Y. Miyamoto, K. Mashima, Chem. Commun. 2011, 47, 8322-8324; c) B. Biannic, A. Aponick, Eur. J. Org. Chem. 2011, 2011, $6605-6617$; d) M. Georgy, V. Boucard, O. Debleds, C. D. Zotto, J.-M. Campagne, Tetrahedron 2009, 65, 1758-1766.

[5] S. Haubenreisser, M. Niggemann, Adv. Synth. Catal. 2011, 353, 469-474.

[6] a) M. Gohain, C. Marais, B. C. B. Bezuidenhoudt, Tetrahedron Lett. 2012, 53, 1048-1050; b) T. Ohshima, J. Ipposhi, Y. Nakahara, R. Shibuya, K. Mashima, Adv. Synth. Catal. 2012, 354, 2447-2452.

[7] J.-M. Yang, R. Jiang, L. Wu, X.-P. Xu, S.-Y. Wang, S.-J. Ji, Tetrahedron 2013, 69, 7988-7994.

[8] a) W. Huang, Q.-S. Shen, J.-L. Wang, X.-G. Zhou, Chin. J. Chem. 2008, 26, 729-735; b) W. Rao, X. Zhang, E. M. L. Sze, P. W. H. Chan, J. Org. Chem. 2009, 74, 1740-1743.

[9] a) R. Jiang, C.-X. Yuan, X.-P. Xu, S.-J. Ji, Appl. Organomet. Chem. 2012, 26, 62-66; b) H. Qin, N. Yamagiwa, S. Matsunaga, M. Shibasaki, Angew. Chem. Int. Ed. 2007, 46, 409-413.

[10] a) X. Giner, P. Trillo, C. Nájera, J. Organomet. Chem. 2011, 696 357-361; b) B. Sreedhar, P. Surendra Reddy, M. Amarnath Reddy, B Neelima, R. Arundhathi, Tetrahedron Lett. 2007, 48, 8174-8177. 
[11] H. Yamamoto, E. Ho, I. Sasaki, M. Mitsutake, Y. Takagi, H. Imagawa, M. Nishizawa, Eur. J. Org. Chem. 2011, 2011, 2417-2420.

[12] P. Trillo, A. Baeza, C. Nájera, Eur. J. Org. Chem. 2012, 2012 , 2929-2934.

[13] P.-A. Payard, Q. Gu, W. Guo, Q. Wang, M. Corbet,C. Michel, P. Sautet, L. Grimaud, R. Wischert, M. Pera-Titus, Chem. Eur. J. 2018, 24 14146-14153.

[14] a) S. Kobayashi, Pure Appl. Chem. 2000, 72, 1373-1380; b) H. Yamamoto, Lewis Acids in Organic Synthesis; Wiley-VCH, Weinheim, 2002; c) H. Yamamoto, K. Ishihara, Acid Catalysis in Modern Organic Synthesis, Wiley-VCH, Weinheim, 2008; d) G. A. Olah, Superacid Chemistry, Wiley-Blackwell, Oxford, 2009

[15] P. Muller, Pure Appl. Chem. 1994, 66, 1077-1184.

[16] a) R. G. Pearson, J. Am. Chem. Soc. 1963, 85, 3533-3539; b) S. Woodward, Tetrahedron 2002, 58, 1017-1050; c) R. G. Pearson, Acc. Chem. Res. 1993, 26, 250-255; d) R. G. Pearson, J. Chem. Sci. 2005 117, 369-377.

[17] a) L. Greb, Chem. Eur. J. 2018, 24, 17881-17896; b) S. Antoniotti, V. Dalla. E. Duñach, Angew. Chem. Int. Ed. 2010, 49, 7860-7888.

[18] a) J. C. Haartz, D. H. McDaniel, J. Am. Chem. Soc. 1973, 95 , 8562-8565; b) H. Böhrer, N. Trapp, D. Himmel, M. Schleep, I. Krossing, Dalton Trans. 2015, 44, 7489-7499.

[19] K. B. Yatsimirskii, Theor. Exp. Chem. 1981, 17, 75-79.

[20] K. P. A. Kepp, Inorg. Chem. 2016, 55, 9461-9470.

[21] a) R. Rousseau, D. A. Dixon, B. D. Kay, Z. Dohnálek, Chem. Soc. Rev. 2014, 43, 7664-7680; b) K. O. Christe, R. Haiges, M. Vasiliu, D. A Dixon, Angew. Chem. Int. Ed. 2017, 56, 7924-7929; c) R. Craciun, D. Picone, R. T. Long, S. Li, R. A. Dixon, K. A. Peterson, K. O. Christe, Inorg. Chem. 2010, 49, 1056-1070; d) K. O. Christe, D. A. Dixon, D. K. McLemore, W. W. Wilson, J. Sheehy, J. A. Boatz, J. Fluor. Chem. 2000 , 101, 151-153.

[22] a) U. Mayer, V. Gutmann, W. Gerger, Monatsh. Chem. 1975, 106 1235-1257; b) M. A. Beckett, G. C. Strickland, J. R. Holland, K. S Varma, Polymer 1996, 37, 4629-4631; c) G. J. P, Britovsek, J. Ugolotti, A. J. P. White, Organometallics 2005, 24, 1685-1691; d) Y. Koito, K Nakajima, H. Kobayashi, R. Hasegawa, M. Kitano, M. Hara, Chem. Eur. J. 2014, 20, 8068-8075; e) A. R. Nödling, K. Müther, V. H. G. Rohde, G. Hilt, M. Oestreich, Organometallics 2014, 33, 302-308.

[23] a) R. F. Childs, Can. J. Chem. 1982, 60, 809-811; b) R. F. Childs, D. L. Mulholland, A. Nixon, Can. J. Chem. 1982, 60, 801-808; c) P. Laszlo, M. Teston, J. Am. Chem. Soc. 1990, 112, 8750-8754

[24] a) G. Hilt, F. Pünner, J. Möbus, V. Naseri, M. A. Bohn, Eur. J. Org. Chem. 2011, 2011, 5962-5966; b) G. Hilt, A. Nödling, Eur. J. Org. Chem. 2011, 2011, 7071-7075.

[25] a) K. F. Purcell, R. S. Drago, J. Am. Chem. Soc. 1966, 88, 919-924; b) B. Swanson, D. F. Shriver, Inorg. Chem. 1970, 9, 1406-1416; c) D. F. Shriver, B. Swanson, Inorg. Chem. 1971, 10, 1354-1365; d) D. M. Byler, D. F. Shriver, Inorg. Chem. 1973, 12, 1412-1416; e) A. G. Pelmenschikov, R. A. van Santen, J. Janchen, E. Meijer, J. Phys. Chem. 1993, 97, 11071-11074; f) P. A. Chase, P. E. Romero, W. E. Piers, M. Parvez, B. O. Patrick, Can. J. Chem. 2005, 83, 2098-2105.

[26] a) R. G. Parr, R. G. Pearson, J. Am. Chem. Soc. 1983, 105, 7512-7516; b) R. G. Parr, W. Yang, J. Am. Chem. Soc. 1984, 106, 4049-4050.

[27] a) A. T. Maynard, M. Huang, W. G. Rice, D. G. Covell, Proc. Ntl. Acad. Sci. 1998, 95, 11578-11583; b) R. G. Parr, L. V. Szentpály, S. Liu, J. Am. Chem. Soc. 1999, 121, 1922-1924; c) A. R. Jupp, T. C. Johnstone, D. W. Stephan, Dalton Trans. 2018, 47, 7029-7035.

[28] a) G. A. Olah, S. Kobayashi, M. Tashiro, J. Am. Chem. Soc. 1972, 94 , 7448-7461; b) S. Kobayashi, S. Nagayama, T. Busujima, J. Am. Chem. Soc. 1998, 120, 8287-8288.

[29] For clarity, the references of this note have been grouped in four categories: i) Crystallographic data of pure triflates, ii) Crystallographic data of triflates with another ligand iii) triflates characterized by other characterization data (IR, NMR, TGA, Titration) iv) described but uncharacterized triflates.

i) Crystallographic data of pure triflates, only lithium triflate was crystalized under anhydrous form: a) R. Dinnebier, N. Sofina, M. Jansen, Z. Anorg. Allg. Chem. 2004, 630, 1613-1616.

ii) Crystallographic data of triflates with another ligand, aluminum (hydrated) b) T. Trella, W. Frank, Acta Cristallogr. E, 2012, 68, m1136m1137; bismuth (hydrated) c) M. Louër, C. Le Roux, J. Dubac, Chem. Mater. 1997, 9, 12, 3012-3016; d) W. Frank, J. G. Reiss, J. Schneider, Angew. Chem. Int. Ed., 1995, 34, 2416-2417; titanium (alkoxy) e) Y.
Motoyama, M. Tanaka, K. Mikami, Inorg. Chim. Acta, 1997, 256, 161-163; f) M. G. Davidson, A. L. Johnson, Eur. J. Inorg. Chem. 2011 2011, 5151-5159; Lanthanide (hydrated) g) C. O. Paiva Santos, E. E. Castellano, L. C. Machado, G. Vicentini, Inorg. Chim. Acta, 1985, 110, 83-86;

iii) other characterization data (IR, NMR, TGA, Titration): Lanthanides h) M. E. M. Hamidi, J.-L. Pascal, Polyhedron 1994, 13, 1787-1792; i) Y. Naohisa, N. Shin, N. Masayoshi, Chem Lett 1995, 24 555-556; cobalt, nickel, copper, iron and gallium j) K. Boumizane, M. H. Herzog-Cance, D. J. Jones, J. L. Pascal, J. Potier, J. Roziere, Polyhedron 1991, 10, 2757-2769; Titanium k) H. M. el Mustapha, J.-L. Pascal, J. Fluorine Chem. 1991, 55, 63-78; Yttrium and Ytterbium, I) M. El Mustapha, M. Hnach, H. Zineddine, J Fluor. Chem. 1998, 88, 139-141;

iv) Some other triflimides were prepared but not characterized: titanium, m) A. H. Martin, E. S. Gould, Inorg. Chem. 1975, 14, 873-877; n) B. B. Dhar, E. S. Gould, Dalton Trans. 2010, 39, 1616- 1619.

[30] For clarity the references of this note have been grouped in four categories: i) Crystallographic data of pure triflimides, ii) Crystallographic data of triflimides with another ligand iii) triflimides characterized by other characterization data (IR, NMR, TGA, Titration) iv) described but uncharacterized triflimides

i) Crystallographic data of pure triflimides: alkali triflimides a) L. Xue, C. W. Padgett, D. D. DesMarteau, W. T. Pennington, Solid State Sci. 2002, 4, 1535-1545; zinc triflimide: b) M. J. Earle, U. Hakala, B. J. McAuley, M. Nieuwenhuyzen, A. Ramani, K. R. Seddon, Chem. Commun. 2004 1368-1369;

ii) Crystallographic data of triflimides with another ligand: alkali-earth (hydrated) c) L. Xue, D. D. DesMarteau, W. T. Pennington, Solid State Sci. 2005, 7, 311-318; d) A. Haas, C. Klare, P. Betz, J. Bruckmann, C. Krüger, Y.-H. Tsay, F. Aubke, Inorg Chem 1996, 35, 1918-1925; rare earths (hydrated) e) M. Kawamura, S. Shimada, Inorg. Chim. Acta 2007, 360, 2162-2168; uranium (oxo, bis(diphenylphosphino)methane) f) S. M. Cornet, I. May, M. P. Redmond, A. J. Selvage, C. A. Sharrad, O Rosnel, Polyhedron 2009, 28, 363-369; copper (carbon monoxide) g) O. G. Polyakov, S. M. Ivanova, C. M. Gaudinski, S. M. Miller, O. P. Anderson, S. H. Strauss, Organometallics 1999, 18, 3769-3771; gold (phospine, N-Heterocyclic Carbene) h) N. Mézailles, L. Ricard, F. Gagosz, Org. Lett. 2005, 7, 4133-4136; i) L. Ricard, F. Gagosz, Organometallics 2007, 26, 4704-4707; titanium, iron and ruthenium (Cp) j) D. B. Williams, M. E. Stoll, B. L. Scott, D. A. Costa, J. W. J. Oldham, Chem. Commun. 2005, 1438-1440;

iii) other characterization data (IR, NMR, TGA, Titration): Lanthanide k) D. B. Baudry, A. Dormond, F. Duris, J. M. Bernard, J. R. Desmurs, J Fluorine Chem. 2003, 121, 233-238; Bismuth I) A. Picot, S. Répichet, C. Le Roux, J. Dubac, N. Roques, J. Fluor. Chem. 2002, 116, 129.

iv) Some other triflimides were prepared but not characterized: manganese, nickel, cobalt, copper, tin and lead triflimide, m) M. J. Earle, U. Hakala, B. J. McAuley, M. Nieuwenhuyzen, A. Ramani, K. R. Seddon, Chem. Commun. 2004, 1368-1369; Aluminum triflimide n) A. Marx, H. Yamamoto, Angew. Chem. Int. Ed. 2000, 39, 178-181 o) K. Mikami, O. Kotera, Y. Motoyama, H. Sakaguchi, M. Maruta, Synlett 1996, 171-172.

[31] a) J. P. Foster, F. Weinhold, J. Am. Chem. Soc. 1980, 102, 7211-7218; b) A. E. Reed, L. A. Curtis, F. Weinhold, Chem. Rev. 1988, 88, 899-926 
